Review Article

\title{
Graft versus Host Disease: From Basic Pathogenic Principles to DNA Damage Response and Cellular Senescence
}

\author{
Adam Kuba $\mathbb{D}$ and Ludek Raida \\ Department of Hemato-Oncology, University Hospital and Faculty of Medicine and Dentistry, Palacky University, \\ Olomouc, Czech Republic \\ Correspondence should be addressed to Adam Kuba; adam.kuba@fnol.cz
}

Received 19 October 2017; Revised 12 February 2018; Accepted 21 February 2018; Published 26 March 2018

Academic Editor: Vinod K. Mishra

Copyright (C) 2018 Adam Kuba and Ludek Raida. This is an open access article distributed under the Creative Commons Attribution License, which permits unrestricted use, distribution, and reproduction in any medium, provided the original work is properly cited.

\begin{abstract}
Graft versus host disease (GVHD), a severe immunogenic complication of allogeneic hematopoietic stem cell transplantation (HSCT), represents the most frequent cause of transplant-related mortality (TRM). Despite a huge progress in HSCT techniques and posttransplant care, GVHD remains a significant obstacle in successful HSCT outcome. This review presents a complex summary of GVHD pathogenesis with focus on references considering basic biological processes such as DNA damage response and cellular senescence.
\end{abstract}

\section{Introduction}

Allogeneic hematopoietic stem cell transplantation (HSCT) offers the only curative modality for many hematological disorders. Due to advances in transplant approaches and supportive care, the use of HSCT is increasing worldwide. Despite such a progress, HSCT is still associated with substantial transplant-related mortality (TRM). Graft versus host disease (GVHD) represents the most frequent cause of TRM. GVHD occurs in about $30-50 \%$ and $70 \%$ of recipients allografted from matched related and matched unrelated donors, respectively [1].

The degree of HLA disparity between donor and recipient is a well-known and widely accepted independent risk factor for GVHD development [2]. With the growing understanding of GVHD pathogenesis, there is increasing attraction to non-HLA genotype as a tool to GVHD prediction in the last ten years [3]. Inherited genetic variants such as single-nucleotide polymorphisms (SNPs) of candidate genes, encoding various cytokines, chemokines, and inflammatory regulators, have become a subject of interest of genetic studies searching for independent predictors of GVHD development and HSCT outcome [4-7]. However, owing to the immense heterogeneity of patients' cohorts and progress in HSCT techniques in the last decade, many of reported results failed to be independently validated $[6,8,9]$.

This review summarizes the updated GVHD pathogenesis linking GVHD with biological processes such as DNA damage response (DDR) and cellular senescence (Figure 1).

\section{GVHD Pathogenesis}

2.1. Acute GVHD. The histocompatibility differences between the donor and the recipient, the presence of donor's immunocompetent cells, and the inability of the recipient to reject these cells were defined as the basic pathogenic prerequisites for GVHD development by Billingham in 1966 [10]. Cytotoxic $\mathrm{T}$ lymphocytes were determined as the cellular effectors of GVHD, and the key role of antigen-presenting cells (APCs) in T-lymphocyte activation was established during the following years $[11,12]$. The current understanding of aGVHD pathogenesis can be summarized as (1) initial tissue damage induced by the conditioning regimen followed by the denudation of auto- and alloantigens accompanied by massive inflammatory cytokine secretion ("cytokine storm") activating APCs, (2) auto- and alloantigen presentation mediated by APCs together with the costimulatory signaling prime donor's cytotoxic $\mathrm{T}$ lymphocytes and 


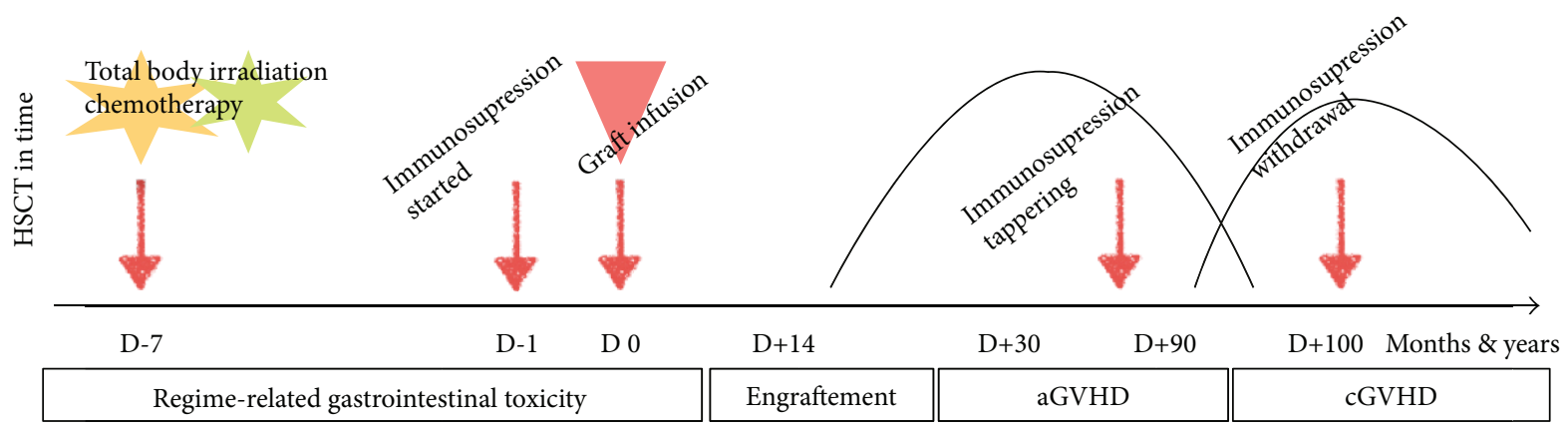

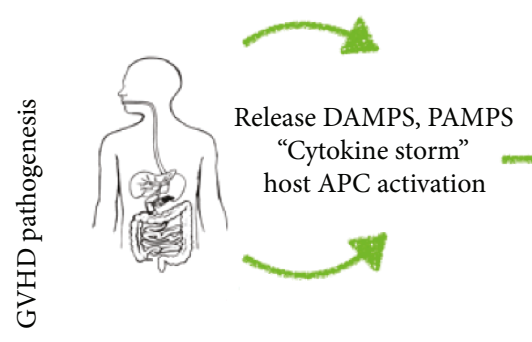

TNFa, IL-1, IL-6

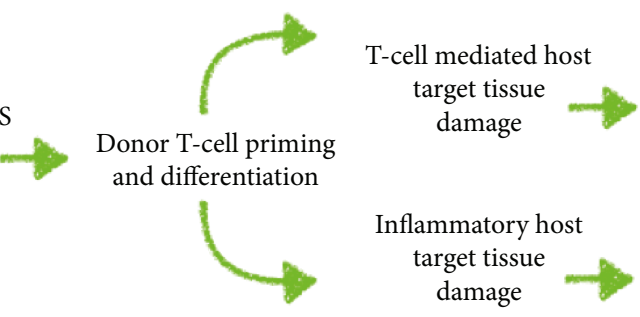

TGFb, IL-2,

IL-4, IL-10

IL-6, IL-12

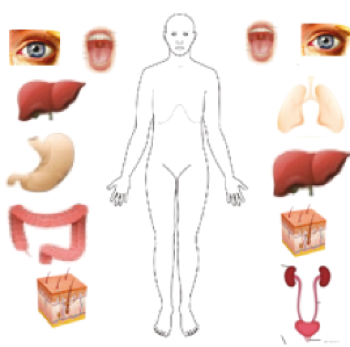

INFy, NO, TNFa, IL-1

FIGURE 1: The upper part of this scheme shows transplant procedure in time with important time points of transplant management. Patients are conditioned with a variety of preparatory regimens. Shortly before graft infusion, GVHD prophylaxis (immunosuppression) is started. Gastrointestinal toxicity occurs during the neutropenic (pre-engraftment) period. Acute GVHD occurs most frequently 30-40 days after engraftment. Later occurrence is typical for late-onset aGVHD, overlap syndrome (features of aGVHD and cGVHD), or cGVHD. GVHD pathogenesis corresponding to transplant time axis is shown in 3 phase-based concepts in the middle of the scheme. Biological processes underlying GVHD pathogenesis are shown at the bottom of the scheme.

their proliferation, and (3) the migration of activated cellular effectors toward GVHD target tissues.

\subsubsection{First Phase: Conditioning-Induced Tissue Damage. The} conditioning-induced damage of recipients' tissues leads to danger signal secretion [13]. Besides the secretion of proinflammatory cytokines (TNF-alpha, IL-1beta, and IL-6), the increased expression of receptor repertoire (pattern recognition receptors, PRR) on APCs, mostly macrophages and dendritic cells, occurs as a result of the release of endogenous and exogenous antigens (damage-associated molecular patterns, DAMPs, and pathogen-associated molecular patterns, PAMPs). High-mobility group box 1 (HMGB1), adenosine-triphosphate (ATP), uric acid, heparan-sulphate proteoglycans (HSPG) as a part of extracellular matrix (ECM), and heat-shock proteins are the most significant DAMPs $[13,14]$. Toll-like receptors (TLR) and other PRR expressed on APCs have the ability to sense endogenous danger signals from DAMPs and are crucial in eliciting alloreactive T-cell responses. Although the elimination of particular DAMPs diminishes aGVHD manifestation in preclinical models, such approach is controversial in clinical praxis especially in HSCT after reduced and nonmyeloablative conditionings with minimal conditioning-induced tissue damage [14].

PAMPs represent a number of pathogen-derived molecules released during the conditioning-induced disruption of natural anti-infective barriers. Lipopolysaccharides (LPS), also called endotoxins, represent the most significant ones. LPS are part of cellular membranes of gram-negative bacteria and are presented by dendritic cells (DC) and macrophages to alloreactive T cells. LPS are ligands of TLR4 playing a key role in innate immunity reactions leading to NF- $\kappa$ B activation followed by pro-inflammatory cytokine secretion [13]. In preclinical models, the chronic exposure to LPS leads to pulmonary GVHD $[15,16]$. However, interest in PAMPs mostly studied in preclinical models subsided in recent years, owing to their undetermined significance in real clinical praxis. There is much more attention being paid to the whole microbiome and its role in GVHD pathogenesis [17]. The impact of intestinal microbiome on GVHD observed in preclinical models historically has recently become a subject of detailed clinical studies due to advances in sophisticated technologies such as culture-independent rRNA gene sequencing [18]. The elimination of certain bacterial species (e.g., Lactobacillus spp.) and the subsequent shift of intestinal microflora in favor of 
pathogenic species (e.g., Enterococcus spp.) due to antibiotic therapy lead to dysbiosis and increased risk of GVHD development [19]. Recent studies have demonstrated that hostderived metabolic products and metabolic products of the intestinal microflora give rise to the intestinal metabolome with possible impact on pathological processes of the gut [20]. Butyrate resulting from the metabolism of complex saccharides in Clostridia directly enhances the presence of T-regulatory lymphocytes (Tregs) in the intestinal tract [21]. Tregs help maintain the intestinal homeostasis by their anti-inflammatory effect. Besides immunomodulatory properties, butyrate is a source of energy for intestinal epithelial cells and also helps maintain the recipient's intestinal barrier integrity while protecting against DAMPs and PAMPs release $[22,23]$. Butyrate improves GVHD-induced intestinal epithelium damage [24].

2.1.2. Second Phase: Activation of Alloreactive T Lymphocytes (Afferent Phase). Disparities in the HLA classes I and II between the donor and the recipient play a major role in the activation of the donor's T lymphocytes. However, GVHD occurs in recipients transplanted from HLA-identical siblings as well. Thus, disparities in the minor HLA are no less important in GVHD development [25]. There have been more than 50 minor HLA identified so far [26]. The tissue specificity of minor HLA and their distribution in different tissue compartments are responsible for GVHD manifestation. Donorderived $\mathrm{T}$ lymphocytes are capable of recognizing antigens on APC originating from both the donor and the recipient $[27,28]$. The binding of the HLA/antigen complex to T-cell receptors (TCR) is not sufficient for T-cell activation. The final immunologic response is controlled by regulatory cosignaling between APC and T lymphocytes having either inhibitory or stimulatory effect [14]. CD28, CD40L, CD30, OX40, 4-1BB, ICOS, and LIGHT are the most significant costimulatory molecules indispensable for T-cell activation [29]. In contrary, CTLA4 or PD-1 is required for the physiologic elimination of autoreactive $\mathrm{T}$ lymphocytes and having inhibitory effect on T-cell activation $[29,30]$.

Subpopulations of T lymphocytes are equally important in the regulation of alloreactivity. Tregs and NK cells inhibit T-cell alloreactivity and diminish GVHD occurrence in preclinical as well as clinical observations [31]. T-cell activation is associated with massive cytokine secretion. Based on different cytokine profiles, CD4+ T lymphocytes are subdivided into Th1, Th2, and Th17 subpopulations. Th1 lymphocytes are involved in GVHD pathogenesis through the production of pro-inflammatory cytokines such as interferon-gamma (INF-gamma), interleukin-2 (IL-2), and tumor-necrotizing factor-alpha (TNF-alpha). However, the actual role of Th1 cytokines in GVHD pathogenesis remains unclear since Th1 cytokines exhibit variable function in different GVHD target organs $[32,33]$. In contrary, Th2 lymphocytes produce IL-4, IL-11, and IL-18 that seem to be protective against GVHD development. According to latest reports, Th17 lymphocytes secreting IL-17 represent highly pro-inflammatory subpopulation capable of inducing GVHD [34]. The loss of balance between subpopulations of CD4+ $\mathrm{T}$ lymphocytes may influence GVHD severity [35].
2.1.3. Third Phase: Chemotaxis and Target Organ Damage (Efferent Phase). Once primed in lymphatic tissues, T lymphocytes migrate toward GVHD target tissues and organs by means of chemotaxis. Although HLA class I is expressed on all nucleated cells of the recipient, the key GVHD target organs are the GI tract, liver, and skin. There have been a lot of hypotheses concerning the site and time of GVHD onset. Organ-specific chemokines drive the migration of alloreactive $\mathrm{T}$ lymphocytes. Inflammatory insults elicit the expression of 4 families of chemokines (CC, CXC, C, and CX3C) at the site of GVHD target tissue. Chemokines interact with their compatible receptors expressed on lymphocytes and the recipient's tissues. The complete list of chemokines and their receptors relevant to GVHD exceeds the extent of this review $[36,37]$.

The final organ damage is mediated by cytotoxic cellular effectors together with inflammatory mediators. The cellular effectors possess several mechanisms of action. Interactions of CD8+ cytotoxic T lymphocytes with target cells result in the release of perforins and granzymes leading to target cell lysis. The activation of apoptotic signaling pathways Fas/FasL (CD95 $\left.{ }^{-}, \mathrm{CD} 95 \mathrm{~L}\right)$ and TNFR/TRAIL represents another mechanism of target cell damage. CD4+ T lymphocytes mediate their effect through Fas/FasL-induced apoptosis primarily [32]. By means of chemotaxis, neutrophils also migrate toward the site of tissue damage contributing to GVHD pathogenesis secondarily [38]. Activated macrophages colocalize with $\mathrm{T}$ lymphocytes at the site of tissue damage and contribute to lytic activity [38].

INF-gamma, TNF-alpha, IL-1, and nitric monoxide produced by $\mathrm{T}$ lymphocytes and monocyte-macrophage system are key inflammatory mediators contributing to target organ damage [32].

2.2. Chronic GVHD. The pathogenesis of $c G V H D$ is much more complex, reflecting its variable clinical manifestation. Mechanisms involved in cGVHD pathogenesis partially overlap with aGVHD, especially in cGVHD developing from pre-existing aGVHD. The pathogenesis of cGVHD is based on alloreactive T-cell and deregulated B-cell interactions as well as innate immunity effectors such as macrophages, dendritic cells, and neutrophils mostly. The activation of profibrotic processes is a consequence of the aforementioned steps. The three phase-based concept of cGVHD pathogenesis is accepted currently [39].

2.2.1. First Phase: Pre-Existing Inflammation. The first phase of cGVHD pathogenesis partially overlaps with aGVHD development and is mediated by innate immunity mechanisms resulting in acute inflammation and nonspecific tissue damage caused by the administration of cytotoxic medications, infections, or previous Th1- and Th17-mediated aGVHD activities. The initial tissue damage may persist, as evidenced by the progressive onset of cGVHD or overlap syndrome. Extensive tissue destruction caused by Th1 and Th17 lymphocytes leads to the release of damage molecules (e.g., ATP, nucleic acids, and HMGB1) that trigger TLR, NOD-like receptor, and inflammasome pathways [40]. The soluble form of ST2 is also released by endothelial cells, 
epithelial cells, and fibroblasts in response to cell damage. It works as a decoy receptor for IL-33 and drives Th2 cells to Th1-cell phenotype, which may be important in the pathogenesis of GVHD [41]. Multiple INF-inducible genes and receptors (PRRs) for PAMPS and DAMPS become upregulated at the time of cGVHD onset [42]. The INF-gamma induced expression of CXCL9, CXCL10, and CXCL11 is responsible for the recruitment of Th1 and NK cells into tissues [43]. Vascular endothelial cells (ECs) are the primary barrier separating donor and recipient tissues. ECs are the first host-derived cells to be exposed to donor immune system. If ECs express and present cognate antigens to alloreactive donor $\mathrm{T}$ cells, they can become susceptible to direct immune attack. Angiogenesis is critical to maintain tissue homeostasis and is modulated by multiple angiocrine factors and cytokines, which recruit inflammatory and immune cells [44]. The immunostimulatory cytosinephosphate-guanosine $(\mathrm{CpG})$ motifs in bacterial DNA bind to PRR (TLR9) resulting in B- and NK-cell activations [45]. CpG oligodeoxynucleotides (ODNs) are TLR9 agonists that show immunostimulatory effect but suppressive impact on angiogenesis [46]. CpG ODN-induced attenuation of angiogenesis is TLR9 dependent. Of interest, increased numbers of TLR9-expressing B cells associated with extensive cGVHD show hypersensitivity to bacteria-derived $\mathrm{CpG}$ in HSCT recipients. Also $\mathrm{CpG}$ response may be useful as a biomarker for both the diagnosis and evaluation of response in cGVHD treatment [47]. Apoptotic EC release LG3, a bioactive fragment of perlecan of functional importance promoting obliterative vascular remodeling [48]. Antiperlecan antibodies (anti-LG3) are accelerators of immune-mediated vascular injury [49]. Anti-LG3, endothelin-1, aminopeptidase $\mathrm{N}$ (sCD13), and IL-2R-alpha are biomarkers of cGVHD [50]. Importantly, anti-LG3 and endothelin-1 are considered markers of vascular inflammation suggesting that these mechanism may contribute to the pathogenesis of cGVHD, where the perturbation of microvasculature occurs [51].

2.2.2. Second Phase: Deregulation of Adaptive Immunity. Thymus damage plays a key role in the second phase, manifesting as chronic inflammation and adaptive immunity deregulation. Thymus dysfunction results in decreased heterogeneity of tissue specific auto-antigens mostly present in cGVHD target organs such as the skin, liver, salivary glands, lungs, eyes, and GI tract. Consequently, donor-derived $\mathrm{T}$ lymphocytes possessing cGVHD antigen specificity and/or cross-reactivity expand [52]. CD4+ Tregs play a key role in peripheral and central tolerance maintenances. Tregs reconstitution is essential for the posttransplant recovery of the immune system [53]. The deficit of Tregs is associated with the significant clinical manifestation of GVHD [54].

Also B lymphocytes have a strong impact on cGVHD pathogenesis. The fate and survival of $\mathrm{B}$ lymphocytes is maintained by the activity of B-cell receptor (BCR) and Bcell activating factor (BAFF) [55]. Posttransplant high BAFF levels and the failure of controlling mechanisms of B-cell activation are associated with persistence and propagation of donor B lymphocytes capable of producing many autoand/or alloantibodies [39]. Probably due to high levels of
BAFF in the plasma of cGVHD patients, donor-derived polyreactive B lymphocytes are capable of escape from peripheral elimination [56]. Thus, BAFF excess expands autoreactive B cells and directly promotes TLR7 and TLR9 expressions responsible for the recognition of RNAassociated antigens and endogenous double-stranded DNA antigens, respectively [57]. Furthermore, TLR7/TLR9 signaling promotes BAFF receptor expression, thus providing a positive feedback loop [58]. There is functional synergy between BCR and TLR7/TLR9 signaling pathways, both increasing B-cell proliferation, cytokine, and autoantibody production [57]. Src kinases including Syk and Lyn kinases are proximal components of BCR signaling pathway and mediate a cross-talk between BCR-TLR pathways upon the ligation of nucleic acids containing immune complexes. Also increased BCR responsiveness with augmented Syk phosphorylation is frequently observed in B cells from patients with CGVHD compared with B cells from patients without cGVHD. The inhibition of Syk abrogates increased BCR responsiveness and $\mathrm{CpG}$ responses in $\mathrm{B}$ cells from patients with cGVHD suggesting possible novel therapeutic targets in cGVHD treatment [59]. Autoreactive antibodies produced by donor B lymphocytes are mainly targeted at minor HLA $[60,61]$. Antibodies directed at antigens derived from chromosome Y (anti-HY) are often detected in male recipients with cGVHD allografted from female donors [60]. Antibodies targeted at platelet-derived growth factor receptor (antiPDGFR) activate the generation of reactive oxygen species (ROS) inducing gene expression for collagen I followed by fibrosis in cGVHD target organs [62]. High levels of antiPDGFR are observed in the plasma of patients with extensive cGVHD [63]. Besides antibody production, B lymphocytes possess the ability of antigen presentation or secretion of regulatory cytokines and chemokines. The actual role of $\mathrm{B}$ lymphocytes in cGVHD pathogenesis is more complex [62]. Recently, the identified subpopulation of B lymphocytes are $\mathrm{CD}^{19+} \mathrm{CD}^{21-/+}$ B-regulatory lymphocytes (Bregs), involved in CGVHD pathogenesis $[64,65]$. The Bregs counts after day +100 correlate with the probability of cGVHD development [66]. Patients with active cGVHD and severe infections show significantly increased levels of immature/ transitional $\mathrm{CD}^{19+} / \mathrm{CD}^{21-} \mathrm{B}$ lymphocytes and significantly lower counts of memory $\mathrm{CD}^{19+} / \mathrm{CD}^{27+} \mathrm{B}$ lymphocytes [67].

Regulatory natural killer (NKregs) cells are a subpopulation of NK cells with immunosuppressive characteristics. NKregs express $\mathrm{CD}^{27+} \mathrm{CD}^{11 \mathrm{~b}}$ low c-Kit ${ }^{+} \mathrm{NKp}^{46+}$ phenotype and produce molecules with immunosuppressive functions (e.g., CTLA4, LAG-3, and PD-1). Kit ${ }^{+}$NKregs indirectly reduce local antigen-presenting capacity by targeting and killing immature dendritic cells [68]. Lower proportions of CD56 bright NKregs were detected in patients with higher cGVHD frequency after filgrastim-stimulated peripheral blood apheresis and bone marrow collection, suggesting their important regulatory role in cGVHD development [69].

2.2.3. Third Phase: Excessive Fibrosis. The third phase of cGVHD pathogenesis is based on deregulated processes in response to chronic inflammation resulting in excessive fibrosis, disruption of the architecture of target tissues and 
organs, and their dysfunction [70, 71]. Physiologic regulatory mechanisms associated with inflammatory response work to suppress and minimize cellular damage restore tissue integrity and homeostasis in order to maintain functional healing. Exuberant or excessive repair lead to fibrosis, scaring, and organ dysfunction. ECM deposition is essential for the initiation and development of healing processes. ECM represents an active factor in cell-ECM interactions. The vascular remodeling and restoration of the epithelia are the prerequisites of functional healing [72, 73]. The differentiation of fibroblasts into ECM-producing myofibroblasts is regulated by the synergism of both, innate and adaptive, immunity reactions. ECM-producing fibroblasts are activated by innate immunity cellular effectors such as myeloid cells producing TNF-alpha, IL-6, and IL-1-beta or macrophages producing TGF-beta, PDGF, or matrix-metalloproteinases (MMPs) [70]. MMPs exhibit proteolytic activities resulting in degradations of several ECM components and are important factors in tissue remodeling [74]. MMP3 is known to promote epithelial-mesenchymal transition resulting in tissue fibrosis [75]. Importantly, MMP3 plasma concentrations increase with time from cGVHD onset and are suggested as a possible biomarker of tissue fibrosis in patients with cGVHD [43]. Macrophages undergo reprogramming during the resolution of inflammation and start producing wound-healing, immune-regulatory, and angiogenic cytokines and growth factors, such as IL-10 or vascular endothelial growth factor (VEGF) [76-78]. Adaptive immunity cellular effectors Th2 and Th17 CD4+ lymphocytes activate profibrotic processes through the production of specific cytokines IL-13 and IL-17. In the preclinical setting, the contribution of B cells to cGVHD-related fibrogenesis has been well documented [79-81].

\section{Focusing on GVHD Pathogenesis from Perspectives of Cellular Senescence}

Alkylating agents and ionizing radiation used in the HSCT conditioning cause severe DNA damage. DDR signaling pathways are sensed and orchestrated by ATM and ATR kinases regulating downstream processes such as DNA repair, cell cycle arrest, cellular senescence, and apoptosis. ATM plays a crucial role in identifying DNA lesions. Rodier et al. showed that senescent cells with continuing lowthreshold DDR signaling due to irreparable DNA lesions secrete a plethora of inflammatory cytokines, chemokines, growth factors, proteases, and ECM components generally known as senescence-associated secretory phenotype (SASP) [82].

3.1. Senescence-Associated Secretory Phenotype. ATM activation in response to DNA damage induces under certain conditions expression of various pro-inflammatory cytokines such as IL-6 and IL-8 [83]. IL-6, a cytokine with pleiotropic effects, is the most prominent SASP member [84]. IL-6 secretion is known to be associated with DNA damage-induced and oncogenic stress-induced senescence of mouse and human keratinocytes, melanocytes, monocytes, fibroblasts, and epithelial cells [85-88]. Both IL-1alpha and IL-1beta

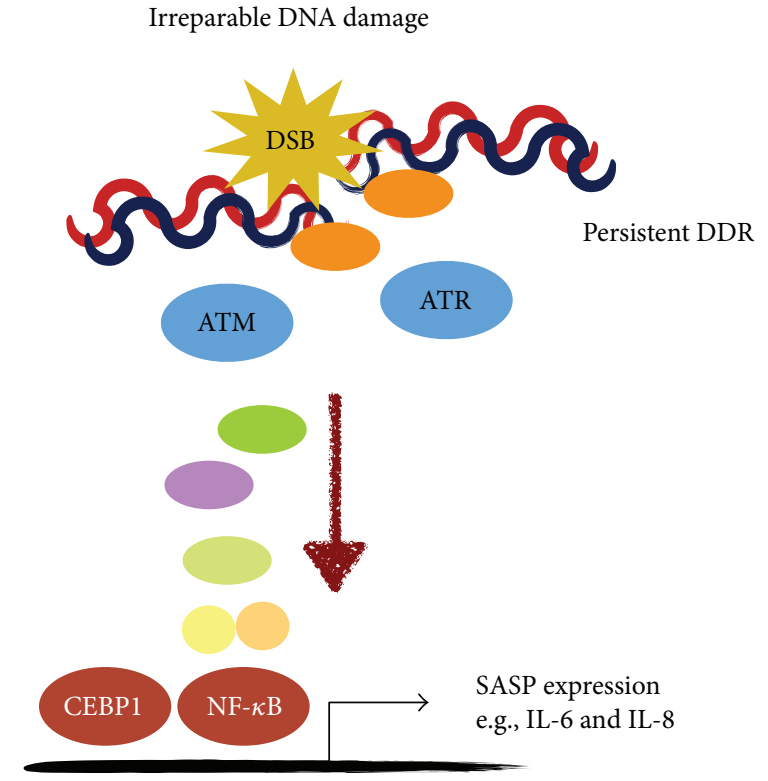

FIgURE 2: ATM kinase has a crucial role in the initiation of SASP in the DNA damage response and is required for the secretion of the two major inflammatory cytokines, for example, IL-6 and IL-8. Persistent DNA damage stimulates NF- $\kappa \mathrm{B}$ signaling, which consequently regulates the expression of various SASP-related genes.

signaling pathway are upregulated in senescent endothelial cells, fibroblasts, and chemotherapy-induced senescent epithelial cells [89-92]. Additional inflammatory cytokines such as the colony-stimulating factors (GM-CSF and GCSF) are secreted at high levels by senescent fibroblasts [86].

Extracellular soluble factors such as the MMP family are equally important subsets of SASP. Of interest, MMPs can cleave some of the monocyte chemoattractant proteins (MCP), IL-8, and a variety of CXCL/CCL family members $[93,94]$. MMPs participate in the resolution of extracellular matrix fibrotic scars, being of immense importance for wound healing and tissue repair or regeneration [86, 95].

Eventually, SASP produces several insoluble ECM components such as fibronectin-a large glycoprotein found in connective tissues, on cell surfaces, and in body fluids. It interacts with other ECM components. Cells undergoing senescence in vivo display increased fibronectin expression [96].

Senescent cells can alter their microenvironment through the secretion of nonprotein substances such as ROS or nitric oxide (NO). These reactive molecules are known to reinforce senescence phenotype and to propagate DNA damage to neighbouring cells [97].

3.2. SASP Regulation, Expansion, and Immune System Activation. Various analyses have proven that SASP gene expression is predominantly controlled by the NF- $\kappa \mathrm{B}$ system [98-100] (Figure 2). The NF- $\kappa \mathrm{B}$ activity is regulated via positive and negative feedback loops and mediated, besides other factors, by IL-1alpha and micro-RNA-146a, respectively [83]. Senescence is reinforced via positive cytokine feedback loops (IL-6 and IL-8), which help maintain the senescent phenotype. 


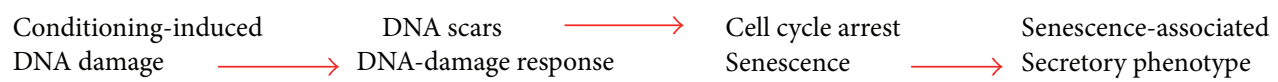

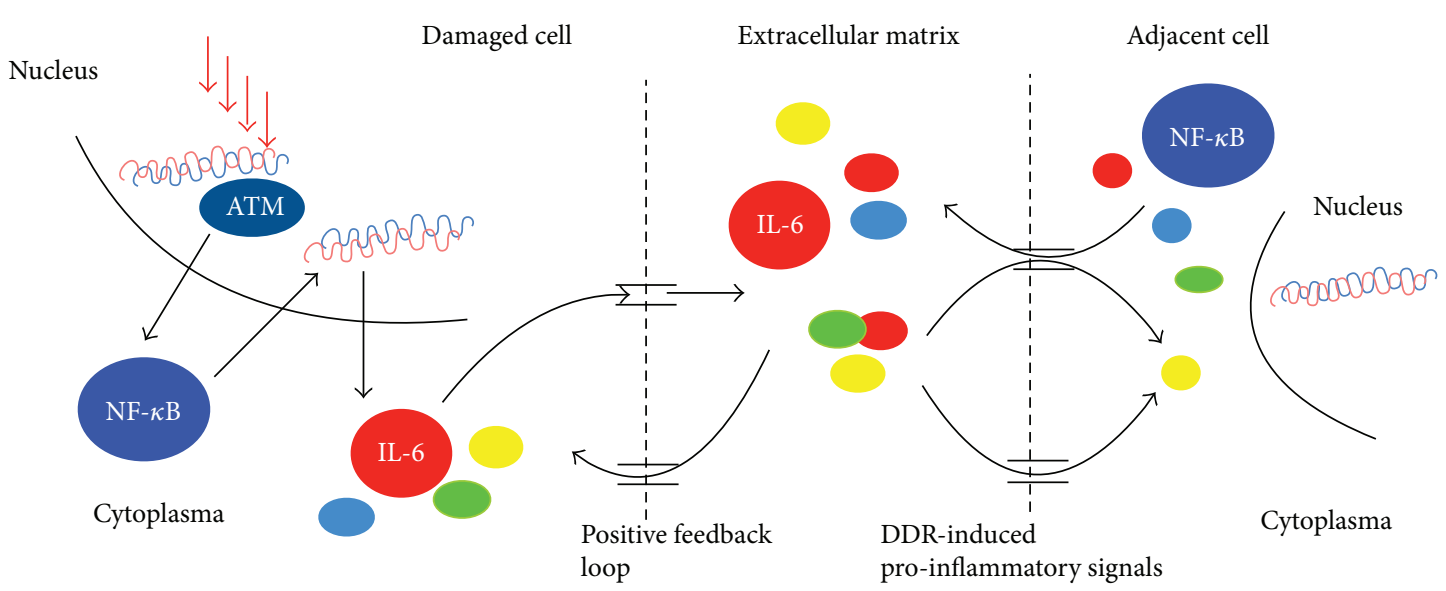

FIGURE 3: Besides other factors, cytokines released in response to DNA damage give rise to the senescence-associated secretory phenotype (SASP). These cytokines reinforce the senescent phenotype via positive feedback loops (IL-6 and IL-8), which help maintain the senescent phenotype. Also, SASP causes the surrounding undamaged cycling cells to irreversibly arrest cycling and become senescent, a phenomenon called by-stander senescence.

Also SASP causes the surrounding undamaged cycling cells to irreversibly arrest cycling and become senescent, a phenomenon called by-stander senescence [101] (Figure 3). Thus, senescent cells communicate with and modulate their microenvironment through SASP signaling. SASP components such as IL-6, IL-8, and MMPs promote tissue repair. Some SASP proteins, together with cell surface ligands and adhesion molecules expressed by senescent cells, eventually attract immune cells that kill and clear senescent cells [102]. NK cells, macrophages, and T cells participate in the clearance of senescent cells [103]. Cells that become senescent after genomic damage are known to express membrane-bound ligands for the major NK-cell receptor (NKG2D) [104].

From longer-time perspective, despite dampening the senescent activity through SASP negative regulatory feedback loops and immune clearance, senescent cells outpace the immune system and accumulate with time, producing SASPmediated low-level chronic inflammation with both beneficial (tissue repair) and deleterious (organ dysfunction) effects [102].

3.3. Cellular Senescence and GVHD: Preliminary Evidence. A recently published report has documented SNPs of the ATM gene in association with increased risk for gastrointestinal (GI) toxicity in allografted patients [105]. ATM-rs189037 situated in the promoter region of ATM gene has been shown to predispose to high-grade GI toxicity in our study [105]. Accordingly, a hypothesis of defective DDR mechanisms in patients carrying predisposing variants of the ATM gene due to insufficient ATM production resulting in higher risk of conditioning-induced tissue damage has been postulated.

As noted, $\mathrm{NF}-\kappa \mathrm{B}$ is an important regulator of innate immunity responses and also a SASP controller. NF- $\kappa$ B system has been well established in GVHD pathogenesis [14]. In GVHD preclinical models, the inhibition of the NF- $\kappa \mathrm{B}$ complex member c-Rel showed the amelioration of GVHD symptoms while preserving the GVT effect [106]. Another $\mathrm{NF}-\kappa \mathrm{B}$ protein subunit RelB was demonstrated to be critical for host APC compartment maturation and function and required for the expansion of donor helper T-cell type 1 (Th1). The targeted inhibition of its nuclear translocation within APC was found as a promising strategy to dissociate effector and regulatory T-cell function in the setting of Th1mediated tissue injury [107]. Importantly, we have shown the association of two SNPs of the NFKB1 gene encoding for the DNA-binding subunit of the NF- $\kappa$ B complex, namely, NFKB1-rs3774937 and NFKB1-rs3774959, to be associated with GVHD development [108]. Micro-RNA-146a as the negative regulator of $\mathrm{NF}-\kappa \mathrm{B}$ activation has been well documented to be involved in GVHD pathogenesis recently $[5,109]$. Association studies of the IL6-174 G/C SNP with GVHD support the significance of IL-6, essential SASP factor, in various steps of GVHD pathogenesis [110-112].

As mentioned previously, also the expression of membrane-bound ligands for NKG2D by senescent cells after DNA damage corresponds with GVHD-related NKG2D expression by $\mathrm{CD}^{8+} \mathrm{T}$-cells in murine models of HSCT [113].

Telomere shortening during lifespan elicits persistent low-level DDR signaling capable of inducing cellular senescence. Interestingly, a recent study has shown that pretransplant age-adjusted telomere length correlates with TRM in allografted patients [114].

Of interest, according to our very recent data, selected immunohistological markers of cellular senescence (e.g., decreased expression of Ki67 and increased expression of p16) may improve histological diagnostics of gut mucosa obtained from patients with GI GVHD symptoms and correlate with the time of their onset, TRM, and overall survival [115].

Selected components with assigned SASP and also GVHD-related effects are summarized in Table 1 [32, 37, $39,43,62,84,86,116-123$ ]. 
TABLE 1: Summary of selected factors involved in SASP production and GVHD pathogenesis.

\begin{tabular}{|c|c|c|c|c|}
\hline Factor & Symbol & SASP-related activity & GVHD-related activity & References \\
\hline Interleukin-6 & IL-6 & $\begin{array}{l}\text { Inflammation, autocrine growth arrest, } \\
\text { cell migration/invasion }\end{array}$ & Initial cytokine storm & $\begin{array}{l}\text { Reviewed in Campisi } \\
\text { [116] and Paczesny } \\
\text { et al. [32] }\end{array}$ \\
\hline Interleukin-8 & $\begin{array}{l}\text { IL-8, } \\
\text { CXCL8 }\end{array}$ & $\begin{array}{l}\text { Inflammation, autocrine growth arrest, } \\
\text { cell migration/invasion }\end{array}$ & Increased in cGVHD & $\begin{array}{l}\text { Reviewed in Campisi } \\
\text { [116] and Pidala et al. } \\
{[119]}\end{array}$ \\
\hline Interleukin-1 & IL-1 & $\begin{array}{l}\text { Positive feedback component, positive } \\
\text { regulator of NF-kB, IL-6 and IL-8 }\end{array}$ & $\begin{array}{l}\text { Initial cytokine storm, secreted by } \\
\text { macrophages during the inflammatory } \\
\text { effector phase of aGVHD }\end{array}$ & $\begin{array}{l}\text { Reviewed in Coppé } \\
\text { et al. [84] and } \\
\text { Paczesny et al. [32] }\end{array}$ \\
\hline $\begin{array}{l}\text { Monocyte } \\
\text { chemoattractant } \\
\text { proteins (CCL } \\
\text { chemokines) }\end{array}$ & $\begin{array}{l}\text { MCPs, } \\
\text { CCLs }\end{array}$ & $\begin{array}{l}\text { Inflammation, autocrine and paracrine } \\
\text { growth arrest, cell migration/invasion }\end{array}$ & Expressed on GVHD target organs & $\begin{array}{l}\text { Coppé et al. [86], } \\
\text { reviewed in Castor } \\
\text { et al. [37] }\end{array}$ \\
\hline Eotaxin-3 & CCL26 & $\begin{array}{l}\text { Chemokine upregulated in senescent } \\
\text { cells }\end{array}$ & T-cell activation marker & $\begin{array}{c}\text { Coppé et al. [86], Luft } \\
\text { et al. } 2011\end{array}$ \\
\hline $\begin{array}{l}\text { Matrix } \\
\text { metalloproteinase(s) }\end{array}$ & MMPs & $\begin{array}{l}\text { Tissue remodeling, wound healing, } \\
\text { resolution of fibrosis, cell migration/ } \\
\text { invasion }\end{array}$ & MMP-3, cGVHD biomarker & $\begin{array}{l}\text { Reviewed in Campisi } \\
\text { [116], Yu et al. [43] }\end{array}$ \\
\hline Fibronectin & & $\begin{array}{l}\text { Interacts with ECM molecules and } \\
\text { affects cell adhesion and survival growth } \\
\text { and migration }\end{array}$ & Chronic cutaneous GVHD & $\begin{array}{l}\text { Reviewed in Coppé } \\
\text { et al. [84], van der } \\
\text { Straaten et al. [121] }\end{array}$ \\
\hline Collagens & $\mathrm{Col}$ & ECM, fibrosis & $\begin{array}{l}\text { Collagen deposition in cGVHD } \\
\text { including bronchiolitis obliterans }\end{array}$ & $\begin{array}{l}\text { Reviewed in Coppé } \\
\text { et al. [84] and Cooke } \\
\text { et al. [39] }\end{array}$ \\
\hline Amphiregulin & AREG & Cell proliferation & Increased in late aGVHD & $\begin{array}{c}\text { Reviewed in Campisi } \\
\text { [116], Holtan et al. } \\
{[117]}\end{array}$ \\
\hline $\begin{array}{l}\text { Vascular endothelial } \\
\text { growth factor }\end{array}$ & VEGF & $\begin{array}{l}\text { Angiogenesis, endothelial cell migration } \\
\text { and invasion }\end{array}$ & $\begin{array}{l}\text { Decreased in patients with steroid- } \\
\text { refractory GVHD }\end{array}$ & $\begin{array}{l}\text { Reviewed in Coppé } \\
\text { et al. [84], Holtan and } \\
\text { Arora [117] }\end{array}$ \\
\hline $\begin{array}{l}\text { Keratinocyte growth } \\
\text { factor }\end{array}$ & $\begin{array}{l}\text { KGF } \\
\text { (FGF7) }\end{array}$ & $\begin{array}{l}\text { Stimulation of cell migration and } \\
\text { invasion }\end{array}$ & $\begin{array}{l}\text { T-cell homeostasis, immune recovery, } \\
\text { thymic regeneration }\end{array}$ & $\begin{array}{l}\text { Coppé et al. [86], } \\
\text { Chaudry et al. } 2016\end{array}$ \\
\hline $\begin{array}{l}\text { Epidermal growth } \\
\text { factor }\end{array}$ & EGF & $\begin{array}{l}\text { Angiogenesis, stimulation of cell } \\
\text { migration and invasion }\end{array}$ & $\begin{array}{l}\text { Decreased in patients with steroid- } \\
\text { refractory GVHD }\end{array}$ & $\begin{array}{l}\text { Tonini et al. 2003, } \\
\text { Holtan et al. [118] }\end{array}$ \\
\hline $\begin{array}{l}\text { Placental growth } \\
\text { factor }\end{array}$ & PIGF & Angiogenesis & $\begin{array}{l}\text { Increased in patients with steroid- } \\
\text { refractory GVHD }\end{array}$ & $\begin{array}{l}\text { Coppé et al. [86], } \\
\text { Holtan et al. [118] }\end{array}$ \\
\hline Nitric oxide & NO & $\begin{array}{l}\text { Modulator of cellular phenotype, } \\
\text { differentiation of monocytes, promotes } \\
\text { DNA damage and aging }\end{array}$ & $\begin{array}{c}\text { Secreted by macrophages during the } \\
\text { inflammatory effector phase of } \\
\text { aGVHD }\end{array}$ & $\begin{array}{l}\text { Rewieved in Coppé } \\
\text { et al. [84] and } \\
\text { Paczesny et al. [32] }\end{array}$ \\
\hline $\begin{array}{l}\text { Reactive oxygen } \\
\text { species }\end{array}$ & ROS & $\begin{array}{l}\text { Modulators of cellular phenotype, } \\
\text { differentiation of monocytes, promote } \\
\text { DNA damage and aging }\end{array}$ & $\begin{array}{l}\text { Autoantibodies associated with } \\
\text { cGVHD induce ROS accumulation } \\
\text { and induce Col-1 expression }\end{array}$ & $\begin{array}{l}\text { Reviewed in Coppé } \\
\text { et al. [84] and Socié } \\
\text { et al. } 2017\end{array}$ \\
\hline
\end{tabular}

\section{Discussion}

Despite advances in transplant techniques and posttransplant care, GVHD remains the most challenging obstacle in the whole process of allogeneic HSCT. Understanding GVHD pathogenesis has dramatically evolved during the last 50 years. Nevertheless, GVHD diagnostics are still mostly based on the careful examination of general and often nonspecific clinical signs and symptoms (Figures 4 and 5).

The lack of specific biomarkers makes GVHD differential diagnostics difficult and may lead to misdiagnoses and less than $50 \%$ response rate to the first-line treatment [124]. Novel insights into GVHD pathogenesis have not come up with new predictors of GVHD refractoriness. Clinical observations conclude that patients with advanced aGVHD are at highest risk for steroid refractoriness [125]. The mortality of patients with clinically severe aGVHD reaches 90\% [126]. Only $20-30 \%$ of patients with refractory GVHD survive one year [124]. The further escalation of immunosuppression is rather deleterious and is associated with poor HSCT outcome, due to infectious complications and the suppression of GVT effect resulting in increased relapse/progression rate [127]. 

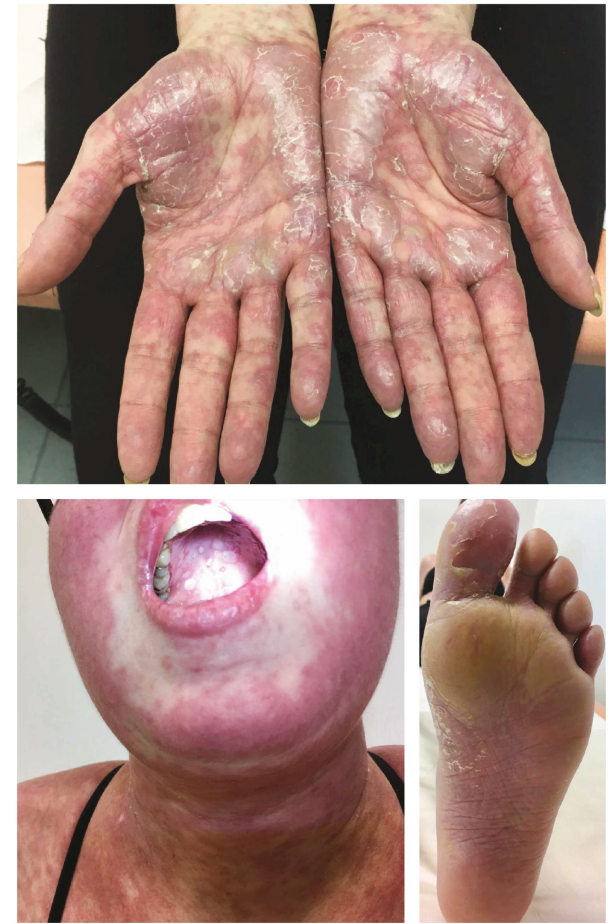

Figure 4: A patient presents with aGVHD after early GVHD prophylaxis withdrawal. Palmar (top) and plantar (bottom right) erythema and bullae formations are typical skin manifestations of aGVHD. The erythema of the face spreads to the neck, chest, and shoulders often resulting into generalized erythroderma. aGVHD manifestation in the oral cavity involves stomatitis and cheilitis (bottom left). The face shows signs of cushingoid features resulting from adverse side effects of corticosteroids.

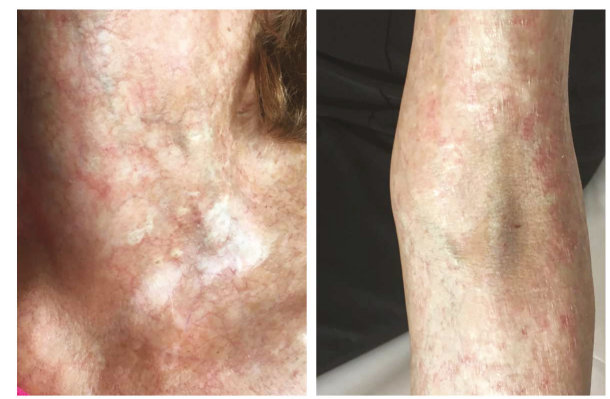

FIGURE 5: A patient after allogeneic HSCT with steroid-refractory cGVHD with dominant skin involvement (poikilodermic and sclerodermic lesions) of the neck (left) and the cubital region (right).

The GI tract harbors a substantial part of the immune system and is a frequent site of aGVHD manifestation. However, there are many other inflammatory processes including opportunistic viral reactivations in severely immunosuppressed patients [128, 129]. Lerner's histopathological classification and its modifications are generally used for GI GVHD [130-132]. However, strong interobserver variability exists [133].

Cellular senescence refers to essentially irreversible cell cycle arrest in response to oncogenic stress, a mechanism formally described as limited growth of human cells in culture by Hayflick more than 50 years ago [134]. Since then, the perception of the mechanisms of cellular senescence has evolved. According to the theory of antagonistic pleiotropy: a biological process that was selected to promote fitness in younger organisms can be deleterious in elder organisms [135]. Likewise, cellular senescence is known to promote tumor suppression and wound healing in young organisms but becomes detrimental with age, most likely by promoting chronic inflammation [116].

The hypotheses mentioned above and supported by so far limited clinical evidence provide suggestions that cellular senescence-a phenomenon in the biology of aging-may contribute to GVHD pathogenesis. These processes may also elucidate mechanisms regulating the time and character of GVHD onset as well as prediction of its therapeutic responsiveness.

\section{Conflicts of Interest}

The authors declare no conflict of interest.

\section{Acknowledgments}

This work was supported by the student project IGA_LF_2018_004 of the Palacky University and Ministry of Health, Czech Republic-conceptual development of research organization (FNOl, 0098892).

\section{References}

[1] M. Jagasia, M. Arora, M. E. D. Flowers et al., "Risk factors for acute GVHD and survival after hematopoietic cell transplantation," Blood, vol. 119, no. 1, pp. 296-307, 2012.

[2] P. J. Martin, G. Schoch, L. Fisher et al., "A retrospective analysis of therapy for acute graft-versus-host disease: initial treatment," Blood, vol. 76, no. 8, pp. 1464-1472, 1990.

[3] A. M. Dickinson, J. L. Harrold, and H. Cullup, "Haematopoietic stem cell transplantation: can our genes predict clinical outcome?," Expert Reviews in Molecular Medicine, vol. 9, no. 29, pp. 1-19, 2007.

[4] A. Takami, "Role of non-HLA gene polymorphisms in graftversus-host disease," International Journal of Hematology, vol. 98, no. 3, pp. 309-318, 2013.

[5] A. M. Dickinson and J. Norden, "Non-HLA genomics: does it have a role in predicting haematopoietic stem cell transplantation outcome?," International Journal of Immunogenetics, vol. 42, no. 4, pp. 229-238, 2015.

[6] J. W. Chien, X. C. Zhang, W. Fan et al., "Evaluation of published single nucleotide polymorphisms associated with acute GVHD," Blood, vol. 119, no. 22, pp. 5311-5319, 2012.

[7] Y. Balavarca, K. Pearce, J. Norden et al., "Predicting survival using clinical risk scores and non-HLA immunogenetics," Bone Marrow Transplant, vol. 50, no. 11, pp. 1445-1452, 2015.

[8] M. Arora, S. J. Lee, S. R. Spellman et al., "Validation study failed to confirm an association between genetic variants in the base excision repair pathway and transplant-related mortality and relapse after hematopoietic cell transplantation," Biology of Blood and Marrow Transplantation, vol. 22, no. 8, pp. 1531-1532, 2016. 
[9] P. J. Martin, W. Fan, B. E. Storer et al., "Replication of associations between genetic polymorphisms and chronic graftversus-host disease," Blood, vol. 128, no. 20, pp. 2450-2456, 2016.

[10] R. E. Billingham, "The biology of graft-versus-host reactions," Harvey Lectures, vol. 62, pp. 21-78, 1966.

[11] N. A. Kernan, N. H. Collins, L. Juliano, T. Cartagena, B. Dupont, and R. J. O'Reilly, "Clonable T lymphocytes in T cell-depleted bone marrow transplants correlate with development of graft-v-host disease," Blood, vol. 68, no. 3, pp. 770-773, 1986.

[12] J. Banchereau and R. M. Steinman, "Dendritic cells and the control of immunity," Nature, vol. 392, no. 6673, pp. 245252, 1998.

[13] T. Toubai, N. D. Mathewson, J. Magenau, and P. Reddy, "Danger signals and graft-versus-host disease: current understanding and future perspectives," Frontiers in Immunology, vol. 7, 2016.

[14] J. Magenau, L. Runaas, and P. Reddy, "Advances in understanding the pathogenesis of graft-versus-host disease," British Journal of Haematology, vol. 173, no. 2, pp. 190-205, 2016.

[15] T. Martinu, K. M. Gowdy, J. L. Nugent et al., "Role of C-C motif ligand 2 and $\mathrm{C}-\mathrm{C}$ motif receptor 2 in murine pulmonary graft-versus-host disease after lipopolysaccharide inhalations," American Journal of Respiratory Cell and Molecular Biology, vol. 51, no. 6, pp. 810-821, 2014.

[16] T. Martinu, C. V. Kinnier, J. Sun et al., "Allogeneic splenocyte transfer and lipopolysaccharide inhalations induce differential $\mathrm{T}$ cell expansion and lung injury: a novel model of pulmonary graft-versus-host disease," PloS One, vol. 9, no. 5, article e97951, 2014.

[17] R. Zeiser, G. Socié, and B. R. Blazar, "Pathogenesis of acute graft-versus-host disease: from intestinal microbiota alterations to donor T cell activation," British Journal of Haematology, vol. 175, no. 2, pp. 191-207, 2016.

[18] D. W. van Bekkum and S. Knaan, "Role of bacterial microflora in development of intestinal lesions from graft-versushost reaction," JNCI: Journal of the National Cancer Institute, vol. 58 , no. 3, pp. 787-790, 1977.

[19] E. Holler, P. Butzhammer, K. Schmid et al., "Metagenomic analysis of the stool microbiome in patients receiving allogeneic stem cell transplantation: loss of diversity is associated with use of systemic antibiotics and more pronounced in gastrointestinal graft-versus-host disease," Biology of Blood and Marrow Transplantation, vol. 20, no. 5, pp. 640-645, 2014.

[20] V. B. Young, "The intestinal microbiota in health and disease," Current Opinion in Gastroenterology, vol. 28, no. 1, pp. 63-69, 2012.

[21] K. Atarashi, T. Tanoue, K. Oshima et al., "Treg induction by a rationally selected mixture of Clostridia strains from the human microbiota," Nature, vol. 500, no. 7461, pp. 232-236, 2013.

[22] J. M. W. Wong, R. de Souza, C. W. C. Kendall, A. Emam, and D. J. A. Jenkins, "Colonic health: fermentation and short chain fatty acids," Journal of Clinical Gastroenterology, vol. 40, no. 3, pp. 235-243, 2006.

[23] T. Teshima, P. Reddy, and R. Zeiser, "Acute graft-versushost disease: novel biological insights," Biology of Blood and Marrow Transplantation, vol. 22, no. 1, pp. 11-16, 2016.
[24] N. Mathewson, A. Mathew, K. Oravecz-Wilson et al., "Unbiased metabolic profiling uncovers a crucial role for the microbial metabolite butyrate in modulating GI epithelial cell damage from Gvhd," Blood, vol. 124, no. 21, p. 536, 2014.

[25] E. Goulmy, R. Schipper, J. Pool et al., "Mismatches of minor histocompatibility antigens between HLA-identical donors and recipients and the development of graft-versus-host disease after bone marrow transplantation," New England Journal of Medicine, vol. 334, no. 5, pp. 281-285, 1996.

[26] E. Spierings, "Minor histocompatibility antigens: past, present, and future," Tissue Antigens, vol. 84, no. 4, pp. 374-360, 2014.

[27] D. K. Newton-Nash, "The molecular basis of allorecognition. Assessment of the involvement of peptide," Human Immunology, vol. 41, no. 2, pp. 105-111, 1994.

[28] K. A. Markey, T. Banovic, R. D. Kuns et al., "Conventional dendritic cells are the critical donor APC presenting alloantigen after experimental bone marrow transplantation," Blood, vol. 113, no. 22, pp. 5644-5649, 2009.

[29] J. Briones, S. Novelli, and J. Sierra, "T-cell costimulatory molecules in acute-graft-versus host disease: therapeutic implications976793," Bone Marrow Research, vol. 2011, 7 pages, 2011.

[30] D. L. Mueller, "Mechanisms maintaining peripheral tolerance," Nature Immunology, vol. 11, no. 1, pp. 21-27, 2009.

[31] M. O. Jamil and S. Mineishi, "State-of-the-art acute and chronic GVHD treatment," International Journal of Hematology, vol. 101, no. 5, pp. 452-466, 2015.

[32] S. Paczesny, D. Hanauer, Y. Sun, and P. Reddy, "New perspectives on the biology of acute GVHD," Bone Marrow Transplant, vol. 45, no. 1, pp. 1-11, 2010.

[33] A. C. Burman, T. Banovic, R. D. Kuns et al., "IFN $\gamma$ differentially controls the development of idiopathic pneumonia syndrome and GVHD of the gastrointestinal tract," Blood, vol. 110, no. 3, pp. 1064-1072, 2007.

[34] K. H. Gartlan, K. A. Markey, A. Varelias et al., "Tc17 cells are a proinflammatory, plastic lineage of pathogenic CD8+ T cells that induce GVHD without antileukemic effects," Blood, vol. 126, no. 13, pp. 1609-1620, 2015.

[35] A. S. Henden and G. R. Hill, "Cytokines in graft-versus-host disease," The Journal of Immunology, vol. 194, no. 10, pp. 4604-4612, 2015.

[36] N. A. Kittan and G. C. Hildebrandt, "The chemokine system: a possible therapeutic target in acute graft versus host disease," Current Topics in Microbiology and Immunology, vol. 341, pp. 97-120, 2010.

[37] M. G. M. Castor, V. Pinho, and M. M. Teixeira, "The role of chemokines in mediating graft versus host disease: opportunities for novel Therapeutics," Frontiers in Pharmacology, vol. 3, 2012.

[38] S. G. Holtan, M. Pasquini, and D. J. Weisdorf, "Acute graftversus-host disease: a bench-to-bedside update," Blood, vol. 124, no. 3, pp. 363-373, 2014.

[39] K. R. Cooke, L. Luznik, S. Sarantopoulos et al., "The biology of chronic graft-versus-host disease: a task force report from the National Institutes of Health Consensus Development Project on Criteria for Clinical Trials in Chronic Graftversus-Host Disease," Biology of Blood and Marrow Transplantation, vol. 23, no. 2, pp. 211-234, 2017.

[40] A. Baroja-Mazo, F. Martín-Sánchez, A. I. Gomez et al., "The NLRP3 inflammasome is released as a particulate danger 
signal that amplifies the inflammatory response," Nature Immunology, vol. 15, no. 8, pp. 738-748, 2014.

[41] M. T. Vander Lugt, T. M. Braun, S. Hanash et al., "ST2 as a marker for risk of therapy-resistant graft-versus-host disease and death," New England Journal of Medicine, vol. 369, no. 6, pp. 529-539, 2013.

[42] F. T. Hakim, S. Memon, P. Jin et al., "Upregulation of IFNinducible and damage-response pathways in chronic graftversus-host disease," The Journal of Immunology, vol. 197, no. 9, pp. 3490-3503, 2016.

[43] J. Yu, B. E. Storer, K. Kushekhar et al., "Biomarker panel for chronic graft-versus-host disease," Journal of Clinical Oncology, vol. 34, no. 22, pp. 2583-2590, 2016.

[44] P. Carmeliet, "Angiogenesis in life, disease and medicine," Nature, vol. 438, no. 7070, pp. 932-936, 2005.

[45] B. R. Blazar, A. M. Krieg, and P. A. Taylor, "Synthetic unmethylated cytosine-phosphate-guanosine oligodeoxynucleotides are potent stimulators of antileukemia responses in naive and bone marrow transplant recipients," Blood, vol. 98, no. 4, pp. 1217-1225, 2001.

[46] J. Wu, W. Su, M. B. Powner et al., "Pleiotropic action of CpGODN on endothelium and macrophages attenuates angiogenesis through distinct pathways," Scientific Reports, vol. 6, no. 1, 2016.

[47] K. She, A. L. Gilman, S. Aslanian et al., "Altered toll-like receptor 9 responses in circulating B cells at the onset of extensive chronic graft-versus-host disease," Biology of Blood and Marrow Transplantation, vol. 13, no. 4, pp. 386-397, 2007.

[48] M. Soulez, E.-A. Pilon, M. Dieudé et al., "The perlecan fragment LG3 is a novel regulator of obliterative remodeling associated with allograft vascular rejection novelty and significance," Circulation Research, vol. 110, no. 1, pp. 94-104, 2012.

[49] H. Cardinal, M. Dieudé, N. Brassard et al., "Antiperlecan antibodies are novel accelerators of immune-mediated vascular injury," American Journal of Transplantation, vol. 13, no. 4, pp. 861-874, 2013.

[50] A. Kariminia, S. G. Holtan, S. Ivison et al., "Heterogeneity of chronic graft-versus-host disease biomarkers: association with CXCL10 and CXCR3+ NK cells," Blood, vol. 127, no. 24, pp. 3082-3091, 2016.

[51] H. M. Shulman, K. M. Sullivan, P. L. Weiden et al., "Chronic graft-versus-host syndrome in man," The American Journal of Medicine, vol. 69, no. 2, pp. 204-217, 1980.

[52] S. Dertschnig, G. Nusspaumer, R. Ivanek, M. M. Hauri-Hohl, G. A. Holländer, and W. Krenger, "Epithelial cytoprotection sustains ectopic expression of tissue-restricted antigens in the thymus during murine acute GVHD," Blood, vol. 122, no. 5, pp. 837-841, 2013.

[53] A. J. Beres and W. R. Drobyski, "The role of regulatory T cells in the biology of graft versus host disease," Frontiers in Immunology, vol. 4, 2013.

[54] A. C. Alho, H. T. Kim, M. J. Chammas et al., "Unbalanced recovery of regulatory and effector $\mathrm{T}$ cells after allogeneic stem cell transplantation contributes to chronic GVHD," Blood, vol. 127, no. 5, pp. 646-657, 2016.

[55] S. Smith and M. Cancro, "BLyS: the pivotal determinant of peripheral B cell selection and lifespan," Current Pharmaceutical Design, vol. 9, no. 23, pp. 1833-1847, 2003.

[56] S. Sarantopoulos, K. E. Stevenson, H. T. Kim et al., “Altered B-cell homeostasis and excess BAFF in human chronic graft-versus-host disease," Blood, vol. 113, no. 16, pp. 38653874, 2009.

[57] A. N. Suthers and S. Sarantopoulos, "TLR7/TLR9- and B cell receptor-signaling crosstalk: promotion of potentially dangerous B cells," Frontiers in Immunology, vol. 8, 2017.

[58] J. R. Groom, C. A. Fletcher, S. N. Walters et al., "BAFF and MyD88 signals promote a lupuslike disease independent of T cells," The Journal of Experimental Medicine, vol. 204, no. 8, pp. 1959-1971, 2007.

[59] J. L. Allen, P. V. Tata, M. S. Fore et al., "Increased BCR responsiveness in B cells from patients with chronic GVHD," Blood, vol. 123, no. 13, pp. 2108-2115, 2014.

[60] D. B. Miklos, H. T. Kim, K. H. Miller et al., "Antibody responses to $\mathrm{H}-\mathrm{Y}$ minor histocompatibility antigens correlate with chronic graft-versus-host disease and disease remission," Blood, vol. 105, no. 7, pp. 2973-2978, 2005.

[61] D. B. Miklos, H. T. Kim, E. Zorn et al., "Antibody response to DBY minor histocompatibility antigen is induced after allogeneic stem cell transplantation and in healthy female donors," Blood, vol. 103, no. 1, pp. 353-359, 2004.

[62] G. Socié and J. Ritz, "Current issues in chronic graft-versushost disease," Blood, vol. 124, no. 3, pp. 374-384, 2014.

[63] S. Svegliati, A. Olivieri, N. Campelli et al., "Stimulatory autoantibodies to PDGF receptor in patients with extensive chronic graft-versus-host disease," Blood, vol. 110, no. 1, pp. 237-241, 2007.

[64] A. de Masson, J.-D. Bouaziz, H. Le Buanec et al., "CD24(hi)CD27+ and plasmablast-like regulatory B cells in human chronic graft-versus-host disease," Blood, vol. 125, no. 11, pp. 1830-1839, 2015.

[65] D. Le Huu, T. Matsushita, G. Jin et al., "Donor-derived regulatory B cells are important for suppression of murine sclerodermatous chronic graft-versus-host disease," Blood, vol. 121, no. 16, pp. 3274-3283, 2013.

[66] H. T. Greinix, Z. Kuzmina, R. Weigl et al., "CD19 + CD21low $B$ cells and CD4 + CD45RA + CD31+ T cells correlate with first diagnosis of chronic graft-versus-host disease," Biology of Blood and Marrow Transplantation, vol. 21, no. 2, pp. 250-258, 2015.

[67] H. T. Greinix, D. Pohlreich, M. Kouba et al., "Elevated numbers of immature/transitional CD21-B lymphocytes and deficiency of memory CD27+ B cells identify patients with active chronic graft-versus-host disease," Biology of Blood and Marrow Transplantation, vol. 14, no. 2, pp. 208-219, 2008.

[68] R. Zeiser and B. R. Blazar, "Pathophysiology of chronic graftversus-host disease and therapeutic targets," New England Journal of Medicine, vol. 377, no. 26, pp. 2565-2579, 2017.

[69] A. Kariminia, S. Ivison, B. Ng et al., "CD56 bright natural killer regulatory cells in filgrastim primed donor blood or marrow products regulate chronic graft-versus-host disease: the Canadian Blood and Marrow Transplant Group randomized 0601 study results," Haematologica, vol. 102, no. 11, pp. 1936-1946, 2017.

[70] T. A. Wynn and T. R. Ramalingam, "Mechanisms of fibrosis: therapeutic translation for fibrotic disease," Nature Medicine, vol. 18, no. 7, pp. 1028-1040, 2012.

[71] V. J. Thannickal, Y. Zhou, A. Gaggar, and S. R. Duncan, "Fibrosis: ultimate and proximate causes," Journal of Clinical Investigation, vol. 124, no. 11, pp. 4673-4677, 2014. 
[72] S. Eming, B. Brachvogel, T. Odorisio, and M. Koch, "Regulation of angiogenesis: wound healing as a model," Progress in Histochemistry and Cytochemistry, vol. 42, no. 3, pp. 115170, 2007.

[73] R. M. Strieter, "What differentiates normal lung repair and fibrosis? Inflammation, resolution of repair, and fibrosis," Proceedings of the American Thoracic Society, vol. 5, no. 3, pp. 305-310, 2008.

[74] A. Page-McCaw, A. J. Ewald, and Z. Werb, "Matrix metalloproteinases and the regulation of tissue remodelling," Nature Reviews Molecular Cell Biology, vol. 8, no. 3, pp. 221-233, 2007.

[75] D. C. Radisky, D. D. Levy, L. E. Littlepage et al., "Raclb and reactive oxygen species mediate MMP-3-induced EMT and genomic instability," Nature, vol. 436, no. 7047, pp. 123127, 2005.

[76] A. Ariel and O. Timor, "Hanging in the balance: endogenous anti-inflammatory mechanisms in tissue repair and fibrosis," The Journal of Pathology, vol. 229, no. 2, pp. 250-263, 2013.

[77] C. N. Serhan and J. Savill, "Resolution of inflammation: the beginning programs the end," Nature Immunology, vol. 6, no. 12, pp. 1191-1197, 2005.

[78] A. Byrne and D. J. Reen, "Lipopolysaccharide induces rapid production of IL-10 by monocytes in the presence of apoptotic neutrophils," The Journal of Immunology, vol. 168, no. 4, pp. 1968-1977, 2002.

[79] M. Srinivasan, R. Flynn, A. Price et al., "Donor B-cell alloantibody deposition and germinal center formation are required for the development of murine chronic GVHD and bronchiolitis obliterans," Blood, vol. 119, no. 6, pp. 1570-1580, 2012.

[80] R. Flynn, J. L. Allen, L. Luznik et al., “Targeting Syk-activated $B$ cells in murine and human chronic graft-versus-host disease," Blood, vol. 125, no. 26, pp. 4085-4094, 2015.

[81] H. Jin, X. Ni, R. Deng et al., "Antibodies from donor B cells perpetuate cutaneous chronic graft-versus-host disease in mice," Blood, vol. 127, no. 18, pp. 2249-2260, 2016.

[82] F. Rodier, J.-P. Coppé, C. K. Patil et al., "Persistent DNA damage signalling triggers senescence-associated inflammatory cytokine secretion," Nature Cell Biology, vol. 11, no. 8, pp. 973-979, 2009.

[83] A. Freund, A. V. Orjalo, P.-Y. Desprez, and J. Campisi, "Inflammatory networks during cellular senescence: causes and consequences," Trends in Molecular Medicine, vol. 16, no. 5, pp. 238-246, 2010.

[84] J.-P. Coppé, P.-Y. Desprez, A. Krtolica, and J. Campisi, “The senescence-associated secretory phenotype: the dark side of tumor suppression," Annual Review of Pathology: Mechanisms of Disease, vol. 5, no. 1, pp. 99-118, 2010.

[85] T. Kuilman, C. Michaloglou, L. C. W. Vredeveld et al., "Oncogene-induced senescence relayed by an interleukindependent inflammatory network," Cell, vol. 133, no. 6, pp. 1019-1031, 2008.

[86] J.-P. Coppé, C. K. Patil, F. Rodier et al., "Senescence-associated secretory phenotypes reveal cell-nonautonomous functions of oncogenic RAS and the p53 tumor suppressor," PLoS Biology, vol. 6, no. 12, pp. 2853-2868, 2008.

[87] S.-Y. Lu, K.-W. Chang, C.-J. Liu et al., "Ripe areca nut extract induces $\mathrm{G} 1$ phase arrests and senescence-associated phenotypes in normal human oral keratinocyte," Carcinogenesis, vol. 27, no. 6, pp. 1273-1284, 2006.
[88] D. Sarkar, I. V. Lebedeva, L. Emdad, D.-c. Kang, A. S. Baldwin Jr., and P. B. Fisher, "Human polynucleotide phosphorylase (hPNPaseold-35): a potential link between aging and inflammation," Cancer Research, vol. 64, no. 20, pp. 7473-7478, 2004.

[89] J. A. Maier, P. Voulalas, D. Roeder, and T. Maciag, "Extension of the life-span of human endothelial cells by an interleukin-1 alpha antisense oligomer," Science, vol. 249, no. 4976, pp. 1570-1574, 1990.

[90] S. Kumar, A. J. Millis, and C. Baglioni, "Expression of interleukin 1-inducible genes and production of interleukin 1 by aging human fibroblasts," Proceedings of the National Academy of Sciences, vol. 89, no. 10, pp. 46834687, 1992.

[91] S. Garfinkel, S. Brown, J. H. Wessendorf, and T. Maciag, "Post-transcriptional regulation of interleukin 1 alpha in various strains of young and senescent human umbilical vein endothelial cells," Proceedings of the National Academy of Sciences, vol. 91, no. 4, pp. 1559-1563, 1994.

[92] B.-D. Chang, M. E. Swift, M. Shen, J. Fang, E. V. Broude, and I. B. Roninson, "Molecular determinants of terminal growth arrest induced in tumor cells by a chemotherapeutic agent," Proceedings of the National Academy of Sciences, vol. 99, no. 1, pp. 389-394, 2002.

[93] G. A. McQuibban, J.-H. Gong, J. P. Wong, J. L. Wallace, I. Clark-Lewis, and C. M. Overall, "Matrix metalloproteinase processing of monocyte chemoattractant proteins generates CC chemokine receptor antagonists with anti-inflammatory properties in vivo," Blood, vol. 100, no. 4, pp. 1160-1167, 2002.

[94] P. E. Van den Steen, A. Wuyts, S. J. Husson, P. Proost, J. Van Damme, and G. Opdenakker, "Gelatinase B/MMP-9 and neutrophil collagenase/MMP-8 process the chemokines human GCP-2/CXCL6, ENA-78/CXCL5 and mouse GCP2/LIX and modulate their physiological activities," European Journal of Biochemistry, vol. 270, no. 18, pp. 3739-3749, 2003.

[95] V. Krizhanovsky, M. Yon, R. A. Dickins et al., "Senescence of activated stellate cells limits liver fibrosis," Cell, vol. 134, no. 4, pp. 657-667, 2008.

[96] T. Kumazaki, M. Kobayashi, and Y. Mitsui, "Enhanced expression of fibronectin during in vivo cellular aging of human vascular endothelial cells and skin fibroblasts," Experimental Cell Research, vol. 205, no. 2, pp. 396-402, 1993.

[97] T. Finkel and N. J. Holbrook, "Oxidants, oxidative stress and the biology of ageing," Nature, vol. 408, no. 6809, pp. 239$247,2000$.

[98] E. Rovillain, L. Mansfield, C. Caetano et al., "Activation of nuclear factor-kappa B signalling promotes cellular senescence," Oncogene, vol. 30, no. 20, pp. 2356-2366, 2011.

[99] E. Crescenzi, F. Pacifico, A. Lavorgna et al., "NF- $\kappa$ B-dependent cytokine secretion controls Fas expression on chemotherapy-induced premature senescent tumor cells," Oncogene, vol. 30, no. 24, pp. 2707-2717, 2011.

[100] Y. Chien, C. Scuoppo, X. Wang et al., "Control of the senescence-associated secretory phenotype by NF- $\kappa \mathrm{B}$ promotes senescence and enhances chemosensitivity," Genes \& Development, vol. 25, no. 20, pp. 2125-2136, 2011.

[101] N. Malaquin, A. Carrier-Leclerc, M. Dessureault, and F. Rodier, "DDR-mediated crosstalk between DNAdamaged cells and their microenvironment," Frontiers in Genetics, vol. 6, 2015. 
[102] F. Rodier and J. Campisi, "Four faces of cellular senescence," The Journal of Cell Biology, vol. 192, no. 4, pp. 547-556, 2011.

[103] J. Campisi, “Aging, cellular senescence, and cancer," Annual Review of Physiology, vol. 75, no. 1, pp. 685-705, 2013.

[104] S. Gasser, S. Orsulic, E. J. Brown, and D. H. Raulet, “The DNA damage pathway regulates innate immune system ligands of the NKG2D receptor," Nature, vol. 436, no. 7054, pp. 1186-1190, 2005.

[105] A. Kuba, L. Raida, F. Mrazek et al., "ATM gene single nucleotide polymorphisms predict regimen-related gastrointestinal toxicity in patients allografted after reduced conditioning," Biology of Blood and Marrow Transplantation, vol. 21, no. 6, pp. 1136-1140, 2015.

[106] Y. Shono, A. Z. Tuckett, S. Ouk et al., “A small-molecule c-Rel inhibitor reduces alloactivation of $\mathrm{T}$ cells without compromising antitumor activity," Cancer Discovery, vol. 4, no. 5, pp. 578-591, 2014.

[107] K. P. A. MacDonald, R. D. Kuns, V. Rowe et al., "Effector and regulatory $\mathrm{T}$-cell function is differentially regulated by RelB within antigen-presenting cells during GVHD," Blood, vol. 109, no. 11, pp. 5049-5057, 2007.

[108] A. Kuba, L. Raida, F. Mrazek et al., "NFKB1 gene singlenucleotide polymorphisms (SNPs): protection against acute and chronic graft-versus-host disease (GvHD) in allografted patients," Biology of Blood and Marrow Transplantation, vol. 22, no. 3, p. S404, 2016.

[109] N. Stickel, G. Prinz, D. Pfeifer et al., "MiR-146a regulates the TRAF6/TNF-axis in donor T cells during GVHD," Blood, vol. 124, no. 16, pp. 2586-2595, 2014.

[110] Z. Ambruzova, F. Mrazek, L. Raida et al., "Association of IL-6 gene polymorphism with the outcome of allogeneic haematopoietic stem cell transplantation in Czech patients," International Journal of Immunogenetics, vol. 35, no. 4-5, pp. 401-403, 2008.

[111] L. Karabon, B. Wysoczanska, K. Bogunia-Kubik, K. Suchnicki, and A. Lange, "IL-6 and IL-10 promoter gene polymorphisms of patients and donors of allogeneic sibling hematopoietic stem cell transplants associate with the risk of acute graft-versus-host disease," Human Immunology, vol. 66, no. 6, pp. 700-709, 2005.

[112] J. Cavet, A. M. Dickinson, J. Norden, P. R. Taylor, G. H. Jackson, and P. G. Middleton, "Interferon- $\gamma$ and interleukin-6 gene polymorphisms associate with graft-versus-host disease in HLA-matched sibling bone marrow transplantation," Blood, vol. 98, no. 5, pp. 1594-1600, 2001.

[113] M. A. Karimi, J. L. Bryson, L. P. Richman et al., "NKG2D expression by CD8+ T cells contributes to GVHD and GVT effects in a murine model of allogeneic HSCT," Blood, vol. 125, no. 23, pp. 3655-3663, 2015.

[114] A. Xhaard, R. Cunha, M. Busson et al., "Clinical profile, biological markers, and comorbidity index as predictors of transplant-related mortality after allo-HSCT," Blood Advances, vol. 1, no. 18, pp. 1409-1413, 2017.

[115] A. Kuba, L. Raida, S. Brychtova et al., "Immunohistological detection of P16, Ki67 and $\beta$-catenin in gut mucosa of allografted patients with symptoms of gastrointestinal (GI) acute graft versus host disease (aGVHD)," Biology of Blood and Marrow Transplantation, vol. 24, no. 3, pp. S200-S201, 2018.

[116] J. Campisi, "Cellular senescence: putting the paradoxes in perspective," Current Opinion in Genetics \& Development, vol. 21, no. 1, pp. 107-112, 2011.
[117] S. G. Holtan and M. Arora, "Angiogenic factors and inflammation in steroid-refractory acute graft-vs-host disease," Translational Research, vol. 167, no. 1, pp. 80-87, 2016.

[118] S. G. Holtan, N. Khera, J. E. Levine et al., "Late acute graftversus-host disease: a prospective analysis of clinical outcomes and circulating angiogenic factors," Blood, vol. 128, no. 19, pp. 2350-2358, 2016.

[119] J. Pidala, M. Sarwal, S. Roedder, and S. J. Lee, "Biologic markers of chronic GVHD," Bone Marrow Transplant, vol. 49, no. 3, pp. 324-331, 2014.

[120] T. Luft, S. Dietrich, C. Falk et al., "Steroid-refractory GVHD: T-cell attack within a vulnerable endothelial system," Blood, vol. 118, no. 6, pp. 1685-1692, 2011.

[121] H. M. van der Straaten, M. R. Canninga-van Dijk, L. F. Verdonck et al., "Extra-domain-A fibronectin: a new marker of fibrosis in cutaneous graft-versus-host disease," Journal of Investigative Dermatology, vol. 123, no. 6, pp. 1057-1062, 2004.

[122] T. Tonini, F. Rossi, and P. P. Claudio, "Molecular basis of angiogenesis and cancer," Oncogene, vol. 22, no. 42, pp. 6549-6556, 2003.

[123] M. S. Chaudhry, E. Velardi, J. A. Dudakov, and M. R. M. van den Brink, "Thymus: the next (re)generation," Immunological Reviews, vol. 271, no. 1, pp. 56-71, 2016.

[124] S. Slater, “Acute Graft-Versus-Host Disease," in Blood and Marrow Transplant Handbook: Comprehensive Guide for Patient Care, R. T. Maziarz and S. Slater, Eds., pp. 167-187, Springer, New York, NY, USA, 2011.

[125] M. Murata, H. Nakasone, J. Kanda et al., "Clinical factors predicting the response of acute graft-versus-host disease to corticosteroid therapy: an analysis from the GVHD Working Group of the Japan Society for Hematopoietic Cell Transplantation," Biology of Blood and Marrow Transplantation, vol. 19, no. 8, pp. 1183-1189, 2013.

[126] M. C. Pasquini, "Impact of graft-versus-host disease on survival," Best Practice \& Research Clinical Haematology, vol. 21, no. 2, pp. 193-204, 2008.

[127] M. T. Rubio, M. Labopin, D. Blaise et al., "The impact of graft-versus-host disease prophylaxis in reduced-intensity conditioning allogeneic stem cell transplant in acute myeloid leukemia: a study from the Acute Leukemia Working Party of the European Group for Blood and Marrow Transplantation," Haematologica, vol. 100, no. 5, pp. 683-689, 2015.

[128] M. Hentrich, D. Oruzio, G. Jäger et al., "Impact of human herpesvirus-6 after haematopoietic stem cell transplantation," British Journal of Haematology, vol. 128, no. 1, pp. 66-72, 2005.

[129] S. Mousset, H. Martin, A. Berger et al., "Human herpes virus 6 in biopsies from patients with gastrointestinal symptoms after allogeneic stem cell transplantation," Annals of Hematology, vol. 91, no. 5, pp. 737-742, 2012.

[130] K. G. Lerner, G. F. Kao, R. Storb, C. D. Buckner, R. A. Clift, and E. D. Thomas, "Histopathology of graft vs. host reaction (GvHR) in human recipients of marrow from HL-A-matched sibling donors," Transplantation Proceedings, vol. 6, no. 4, pp. 367-371, 1974.

[131] G. E. Sale, H. M. Shulman, G. B. Mcdonald, and E. Donnall THomas, "Gastrointestinal graft-versus-host disease in man: a clinicopathologic study of the rectal biopsy," The American Journal of Surgical Pathology, vol. 3, no. 4, pp. 291-300, 1979. 
[132] H. M. Shulman, D. M. Cardona, J. K. Greenson et al., "NIH consensus development project on criteria for clinical trials in chronic graft-versus-host disease: II. The 2014 Pathology Working Group Report," Biology of Blood and Marrow Transplantation, vol. 21, no. 4, pp. 589-603, 2015.

[133] A. Kreft, on behalf of the Gastrointestinal Pathology Group of the German-Austrian-Swiss GvHD Consortium, A. Mottok et al., "Consensus diagnostic histopathological criteria for acute gastrointestinal graft versus host disease improve interobserver reproducibility," Virchows Archiv, vol. 467, no. 3, pp. 255-263, 2015.

[134] L. Hayflick, "The limited in vitro lifetime of human diploid cell strains," Experimental Cell Research, vol. 37, no. 3, pp. 614-636, 1965.

[135] C. Rauser, L. Mueller, and M. Rose, "The evolution of late life,” Ageing Research Reviews, vol. 5, no. 1, pp. 14-32, 2006. 


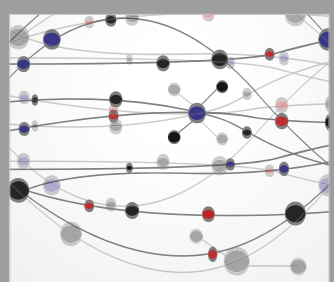

The Scientific World Journal
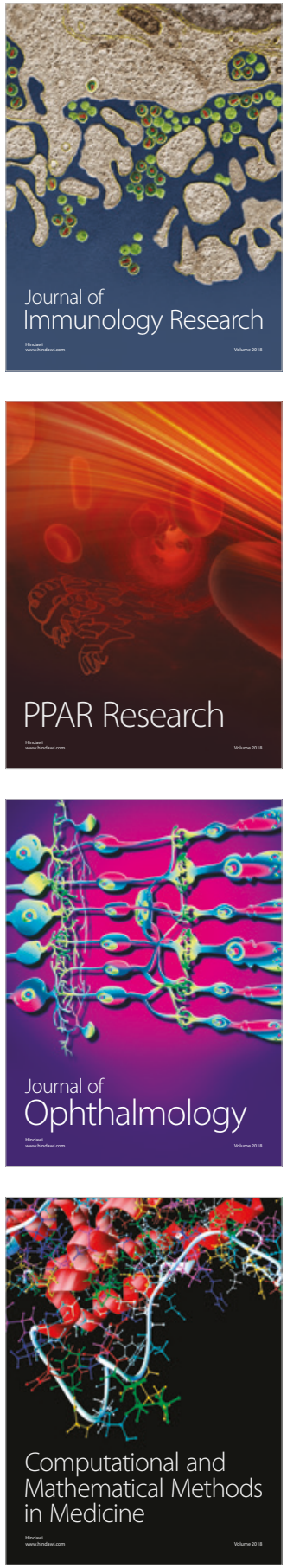

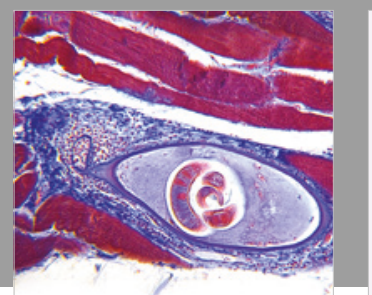

Gastroenterology Research and Practice

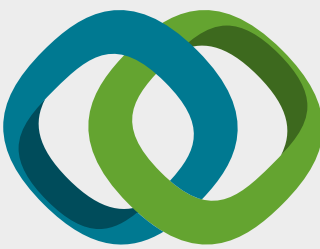

\section{Hindawi}

Submit your manuscripts at

www.hindawi.com
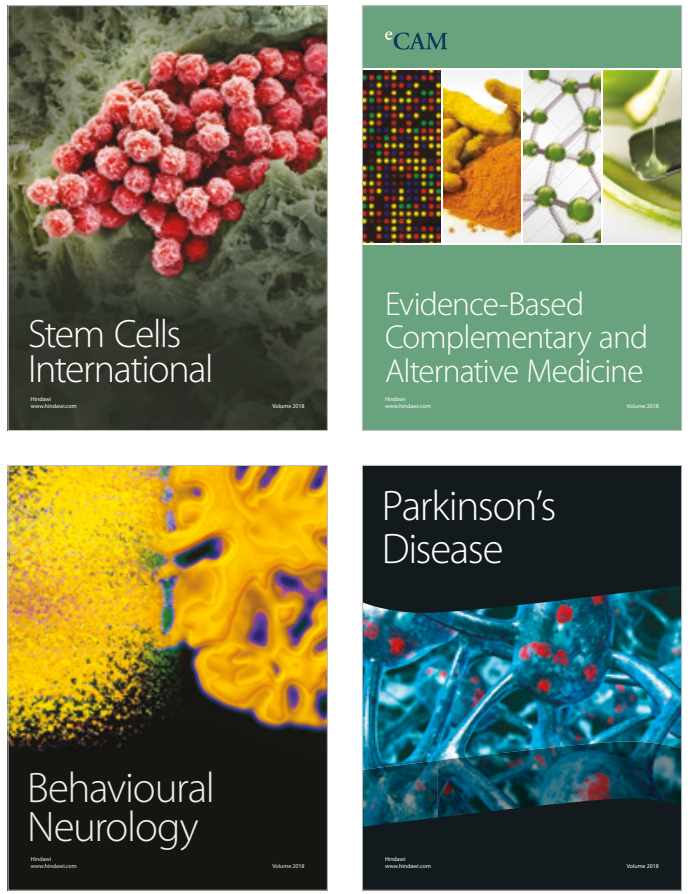

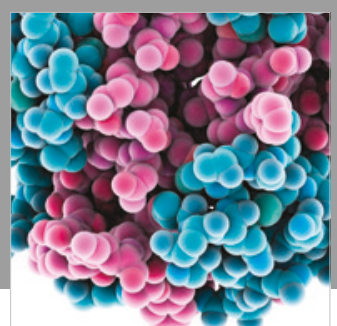

ournal of

Diabetes Research

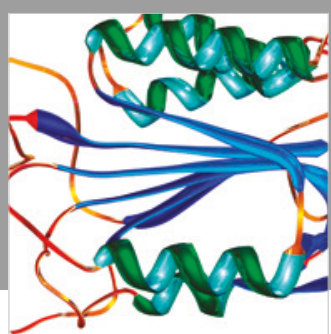

Disease Markers
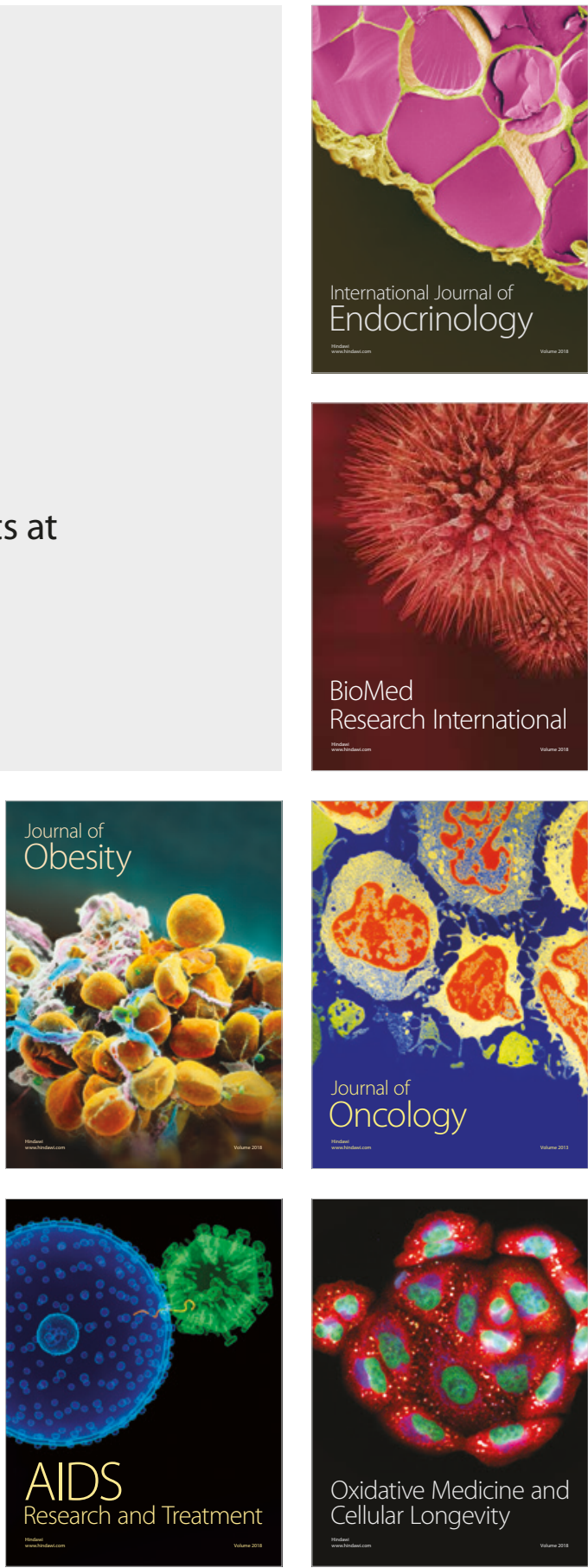